\title{
Determination, speciation and distribution of mercury in soil in the surroundings of a former chlor-alkali plant: assessment of sequential extraction procedure and analytical technique
}

Tiberiu Frentiu ${ }^{1 *}$, Bogdan Petru Pintican², Sanziana Butaciu', Alin Ironim Mihaltan², Michaela Ponta' and Maria Frentiu ${ }^{2}$

\begin{abstract}
Background: The paper presents the evaluation of soil contamination with total, water-available, mobile, semimobile and non-mobile $\mathrm{Hg}$ fractions in the surroundings of a former chlor-alkali plant in connection with several chemical soil characteristics. Principal Component Analysis and Cluster Analysis were used to evaluate the chemical composition variability of soil and factors influencing the fate of $\mathrm{Hg}$ in such areas. The sequential extraction EPA 3200-Method and the determination technique based on capacitively coupled microplasma optical emission spectrometry were checked.

Results: A case study was conducted in the Turda town, Romania. The results revealed a high contamination with $\mathrm{Hg}$ in the area of the former chlor-alkali plant and waste landfills, where soils were categorized as hazardous waste. The weight of the $\mathrm{Hg}$ fractions decreased in the order semi-mobile $>$ non-mobile > mobile $>$ water leachable. Principal Component Analysis revealed 7 factors describing chemical composition variability of soil, of which 3 attributed to $\mathrm{Hg}$ species. Total $\mathrm{Hg}$, semi-mobile, non-mobile and mobile fractions were observed to have a strong influence, while the water leachable fraction a weak influence. The two-dimensional plot of PCs highlighted 3 groups of sites according to the $\mathrm{Hg}$ contamination factor. The statistical approach has shown that the $\mathrm{Hg}$ fate in soil is dependent on $\mathrm{pH}$, content of organic matter, $\mathrm{Ca}, \mathrm{Fe}, \mathrm{Mn}, \mathrm{Cu}$ and $\mathrm{SO}_{4}^{2-}$ rather than natural components, such as aluminosilicates. Cluster analysis of soil characteristics revealed 3 clusters, one of which including $\mathrm{Hg}$ species. Soil contamination with $\mathrm{Cu}$ as sulfate and $\mathrm{Zn}$ as nitrate was also observed.

Conclusions: The approach based on speciation and statistical interpretation of data developed in this study could be useful in the investigation of other chlor-alkali contaminated areas. According to the Bland and Altman test the 3-step sequential extraction scheme is suitable for $\mathrm{Hg}$ speciation in soil, while the used determination method of $\mathrm{Hg}$ is appropriate.
\end{abstract}

Keywords: Mercury determination, Mercury speciation, Principal component analysis, Custer analysis, Capacitively coupled plasma microtorch

\footnotetext{
* Correspondence: ftibi@chem.ubbcluj.ro

${ }^{1}$ Faculty of Chemistry and Chemical Engineering, Babes-Bolyai University, 11

Arany Janos, 400028, Cluj-Napoca, Romania

Full list of author information is available at the end of the article
} 


\section{Background}

Mercury is considered one of the most toxic elements in almost all forms even in low concentrations as a result of bioavailability, mobility and high bioaccumulation factor (biomagnification factor up to $10^{6}$ in the food chain) [1-3]. For this reason its determination and speciation is of great interest in all environmental compartments, such as soil, airborne particulate matter and dust, sediment, water, waste, air and biological samples [4-10]. Natural sources of $\mathrm{Hg}$ emission account for $5207 \mathrm{Mg}$ $\mathrm{yr}^{-1}$, while the anthropogenic contribution is estimated to account for $2320 \mathrm{Mg} \mathrm{yr}^{-1}$, of which more than $95 \%$ has been released during the last century $[11,12]$. The main natural sources of $\mathrm{Hg}$ relate to evasion from marine surface waters, biomass burning and volcanoes emission making $\mathrm{Hg}$ contamination a global concern. The anthropogenic occurrence of $\mathrm{Hg}$ from local sources can create hotspots as is the case of fossil-fuel fired power plants and recently biocombustible, mining (cinnabar, gold, polymetallic ores), processing of non-ferrous metals, cement plants, municipal and medical waste incinerators, chlor-alkali facilities. The diffuse anthropogenic sources of $\mathrm{Hg}$ include traffic, human crematories, biomass and coal burning for domestic heating and uncollected waste products (fluorescent lamps, batteries, thermometers, non- and biodegradable packaging materials, etc.). As a result, the studies related to total $\mathrm{Hg}$ concentration in soil and plants, as well as the distribution of its species in soil nearby chlor-alkali facilities [13], cinnabar mine [14,15], urbane areas [16], agricultural and forest zones [17] are of great interest. Only monitoring total $\mathrm{Hg}$ in environment gives limited data and speciation analysis is mandatory as it provides more useful information related to anthropogenic sources, distribution of $\mathrm{Hg}$ forms, potential toxicity and health risk. The non-chromatographic methods are useful tools in environmental studies for providing operationallydefined fractionation of $\mathrm{Hg}$ species following single or sequential extraction in specific reagents $[13-15,18,19]$.

Determination of $\mathrm{Hg}$ in environmental solid samples involves cold vapor (CV) generation from digested samples in acidic media and detection by atomic fluorescence spectrometry (CV-AFS) and optical emission spectrometry or mass spectrometry in inductively coupled plasma (CV-ICP-OES, CV-ICP-MS) [13,20-22]. Alternatives to these conventional methods are direct release of $\mathrm{Hg}$ vapor by thermal desorption from solid sample and detection by atomic absorption spectrometry $[4,14,16]$. The development of methods for $\mathrm{Hg}$ determination meeting green analytical chemistry demands such as microplasma sources/microtorches of low power and low Ar consumption equipped with microspectrometers has became in recent years an innovative field [23-25]. In line with this trend a miniature equipment with a capacitively coupled plasma microtorch and detection by optical emission spectrometry was developed in our laboratory and successfully applied for $\mathrm{Hg}$ determination in different materials after digestion and $\mathrm{CV}$ generation (CV- $\mu$ CCP-OES) [26,27]. Recently it has been demonstrated that the analytical technique based on $\mathrm{CV}-\mu \mathrm{CCP}$ OES provides figures of merit for $\mathrm{Hg}$ determination in soil similar to the standardized CV-AFS [28].

The aim of this study was the assessment of soil contamination with $\mathrm{Hg}$ by determining total content as well as water-available, mobile, semi-mobile and non-mobile fractions of $\mathrm{Hg}$ in samples collected from an area under the influence of a former chlor-alkali plant in Romania.

\section{Experimental}

\section{Site description and sample collection}

The case study refers to the Turda town, a former industrial center in north-western Romania. The local economy was based mainly on chemical industry, building materials (cement), glass, porcelain and metallurgy. The Turda Chemical Plant founded in 1911 and closed more that 15 years ago generated an important contamination of soil with $\mathrm{Hg}$ from chlor-alkali electrolysis, but also with other metals such as $\mathrm{Cu}$ and $\mathrm{Zn}$. The manufactured compounds were sodium hydroxide, chlorine, hydrochloric acid, copper pesticides, Fe, Zn, Na and K salts, and Ca hypochlorite. After 1998 the industrial facilities were closed and partially demolished. No measures were undertaken for soil remediation so that $\mathrm{Hg}$ has remained a pollutant of concern in the area of the former chemical plant and perhaps also in the residential zone. Currently, the cement factory is also closed and only a distribution unit has remained in the zone. Several existing manufacturing units related to gypsum cardboard and adhesives do not represent pollution sources.

A number of 38 soil samples were collected from a depth between 20 and $30 \mathrm{~cm}$ during May 2013 from the perimeter of the former chlor-alkali plant (7) and waste landfills (5), and residential area (26). Samples were transported in polyethylene bags to laboratory.

\section{Reagents, standard solutions and CRMs.}

Nitric acid, 65\% ultrapure, hydrochloric acid, 37\% ultrapure, sulfuric acid 98\%, ultrapure and ethanol for chromatography (Merck, Darmstadt, Germany) were used for soil sample preparation. Standard solution of $1000 \mathrm{mg} / \mathrm{l} \mathrm{Hg}$ (Merck, Darmstadt, Germany) was used to prepare working standards in the range $0.1-10 \mathrm{ng}$ / $\mathrm{ml}$ stabilized in $5 \%(\mathrm{v} / \mathrm{v}) \mathrm{HCl}$. Stannous chloride dihydrate for mercury determination (Merck, Darmstadt, Germany) served to prepare $20 \%$ (w/v) $\mathrm{SnCl}_{2}$ in $15 \%$ (v/v) $\mathrm{HCl}$ as derivatization reagent. The $\mathrm{BrCl}$ solution prepared by dissolution of $1.50 \mathrm{~g} \mathrm{KBr}(99.9+\%$ p.a.) and 
$1.08 \mathrm{~g} \mathrm{KBrO}_{3}$ (99.9 +\% p.a.) in $100 \mathrm{ml}$ concentrated $\mathrm{HCl}$ was used for oxidation of the organic matter in aqueous extracts, while the $12 \%(\mathrm{w} / \mathrm{v})$ hydroxylamine in water for reducing the excess of $\mathrm{BrCl}$. The ICP multielement standard solution IV $1000 \mathrm{mg} / \mathrm{l}$ (Merck, Darmstadt, Germany) was used to prepare multielement working standards in the range $0-25 \mu \mathrm{g} / \mathrm{ml}$ by dilution with $2 \%$ $\mathrm{HNO}_{3}$ necessary in the determination of $\mathrm{Al}, \mathrm{Ba}, \mathrm{Ca}, \mathrm{Cr}$, $\mathrm{Cu}, \mathrm{Fe}, \mathrm{K}, \mathrm{Li}, \mathrm{Mg}, \mathrm{Mn}, \mathrm{Na}, \mathrm{Sr}$ and $\mathrm{Zn}$ by ICP-OES. Solutions of $0.1 \mathrm{~N} \mathrm{~K}_{2} \mathrm{Cr}_{2} \mathrm{O}_{7}$ and $0.2 \mathrm{~N}$ Mohr's salt were prepared for the determination of organic matter. Solutions necessary for the determination of leachable content of $\mathrm{Cl}^{-}, \mathrm{NO}_{3}^{-}$and $\mathrm{SO}_{4}^{2-}$ by high performance liquid chromatography were prepared according to SR ISO 10304-1:2007. All solutions were prepared with Milli-Q $(18 \mathrm{M} \Omega / \mathrm{cm}$ ) water obtained in laboratory (Millipore Corp., Bedford, USA).

Four certified reference materials, RTC-CRM048-50G Trace Metals Sand 1, RTC-CRM025-050 Soil (Sandy loam-Metals), LGC6141 Soil contaminated with clinker ash and LGC6135 Soil-Hackney Brick Works (LGC Promochem, Wesel, Germany), were analyzed to check the accuracy of the $\mathrm{Hg}$ measurements by $\mathrm{CV}-\mu \mathrm{CCP}-\mathrm{OES}$.

\section{Soil sample preparation and characterization}

Besides $\mathrm{Hg}$, other soil chemical characteristics $(\mathrm{pH}$, organic matter, total content of 13 metals and water leachable content of $\mathrm{Cl}^{-}, \mathrm{NO}_{3}^{-}$and $\mathrm{SO}_{4}^{2-}$ ) were considered. The pollution with $\mathrm{Hg}$ was assessed by soil ranking on different categories related to the alert, intervention levels and contamination factor. Considering the contaminated soil as waste a classification on three categories was also made based on the leachability assay.

Samples were dried at room temperature to avoid $\mathrm{Hg}$ loss and the soil moisture was determined on a parallel sample at $105 \pm 5^{\circ} \mathrm{C}$. For the determination of total $\mathrm{Hg}$ and the other metals the soil samples were mineralized with aqua regia as specified in SR ISO 11466:1995. An amount of $250 \mathrm{mg}$ test soil sample ground and sieved to $<250 \mu \mathrm{m}$ was subjected to microwave-assisted digestion with $12 \mathrm{ml}$ aqua regia using the program given in ref. [28]. The digest was filtered and diluted to $100 \mathrm{ml}$ ultrapure water. Soil samples were subjected to water leaching following the procedure SR ISO 12457-1:2003 at a liquid-to-solid ratio of 2:1 to determine the $\mathrm{Hg}$ available fraction and concentration of anions $\left(\mathrm{Cl}^{-}, \mathrm{NO}_{3}^{-}, \mathrm{SO}_{4}^{2-}\right)$. An amount of wet sample sieved through the $4 \mathrm{~mm}$ sieve corresponding to $175 \mathrm{~g}$ dry sample was leached in the REAX 20 shaker (Heidolph, Schwabach, Germany) for $24 \pm 0.5 \mathrm{~h}$ at room temperature $\left(20 \pm 5^{\circ} \mathrm{C}\right)$ with a volume of water corresponding to a liquid-to-solid ratio of 2:1. Mercury species fractionation as: (i) mobile; (ii) semi-mobile and (iii) non-mobile involved a 3-step sequential extraction according to EPA 3200 scheme [19].
The mobile fraction contains organic $\left(\mathrm{CH}_{3} \mathrm{HgCl}\right)$ and inorganic $\mathrm{Hg}^{2+}$ species (chloride, nitrate, sulfate, oxide and hydroxide). The semi-mobile $\mathrm{Hg}$ species in soil relates mainly to elemental $\mathrm{Hg}$ and possibly amalgams, while the non-mobile fraction to sulfide $(\mathrm{HgS})$ and calomel $\left(\mathrm{Hg}_{2} \mathrm{Cl}_{2}\right)$.

Step 1. Mobile Hg species fraction: $1.5 \mathrm{~g}$ test soil sample was subjected to $3 \times 2.5 \mathrm{ml} 2 \%(\mathrm{v} / \mathrm{v}) \mathrm{HCl}$ and $10 \%$ (v/v) ethanol ultrasound assisted extraction at $60 \pm 2^{\circ} \mathrm{C}$ for $7 \mathrm{~min}$ each time. After each extraction the supernatant was separated by centrifugation at $3100 \mathrm{rpm}$ for 5 minutes. After the last extraction the residue was washed with $2.5 \mathrm{ml}$ ultrapure water by manual shaking for $1 \mathrm{~min}$, then the supernatant was separated by centrifugation. The extracts and rinse were combined.

Step 2. Semi-mobile $\mathrm{Hg}$ species fraction: the residue from the first step was washed with portions of $5 \mathrm{ml}$ warm water of $60 \pm 2^{\circ} \mathrm{C}$ in the ultrasound bath for $5 \mathrm{~min}$ each time until the supernatant was free of $\mathrm{Cl}^{-}$. Rinses were discarded. Extraction was performed twice with $5 \mathrm{ml}$ 1:2 $\mathrm{HNO}_{3}$ on water bath at $95 \pm 2^{\circ} \mathrm{C}$ for $20 \mathrm{~min}$. The residue was rinsed with $5 \mathrm{ml}$ ultrapure water in ultrasound bath for $1 \mathrm{~min}$. Extracts and rinse were combined.

Step 3. Non-mobile $\mathrm{Hg}$ species fraction: The residue from the previous step was extracted twice with $5 \mathrm{ml}$ 1:6:7 (v/v/v) $\mathrm{HCl}: \mathrm{HNO}_{3}: \mathrm{H}_{2} \mathrm{O}$ for $20 \mathrm{~min}$ at $95 \pm 2^{\circ} \mathrm{C}$ on water bath. Supernatants were separated by centrifugation, while the residue was washed by manual shaking with $5 \mathrm{ml}$ ultrapure water for $1 \mathrm{~min}$. Extracts and rinse were combined.

Appropriate aliquot volumes from each extract were subjected to oxidation with $500 \mu \mathrm{BrCl}$ solution and the excess was reduced with $500 \mu \mathrm{l} 12 \%$ hydroxylamine. Then $2.5 \mathrm{ml}$ concentrated $\mathrm{HCl}$ were added and the sample was diluted to $50 \mathrm{ml}$ with water.

For the determination of organic matter an amount of $0.5 \mathrm{~g}$ soil was oxidized at $100^{\circ} \mathrm{C}$ with $10 \mathrm{ml} 0.1 \mathrm{~N}$ $\mathrm{K}_{2} \mathrm{Cr}_{2} \mathrm{O}_{7}$ solution in the presence of $20 \mathrm{ml} 98 \% \mathrm{H}_{2} \mathrm{SO}_{4}$. After cooling, the excess of $\mathrm{K}_{2} \mathrm{Cr}_{2} \mathrm{O}_{7}$ was back titrated with a solution of $0.2 \mathrm{~N}$ Mohr's salt in the presence of o-phenanthroline as indicator [29].

For the determination of soil $\mathrm{pH}$ a 1:5 (volume fraction) suspension of soil in water was prepared according to ISO 10390:2005.

The concentrations of anions in the water leachate were determined following the procedure given in ISO 10304-1:2007 for water quality control.

\section{Methods}

\section{Soil analysis}

The CV- $\mu$ CCP-OES analytical system used for $\mathrm{Hg}$ determination (Figure 1) consists of a capacitively coupled plasma microtorch, a radiofrequency generator as plasma power source, an Ocean Optics QE65 Pro 


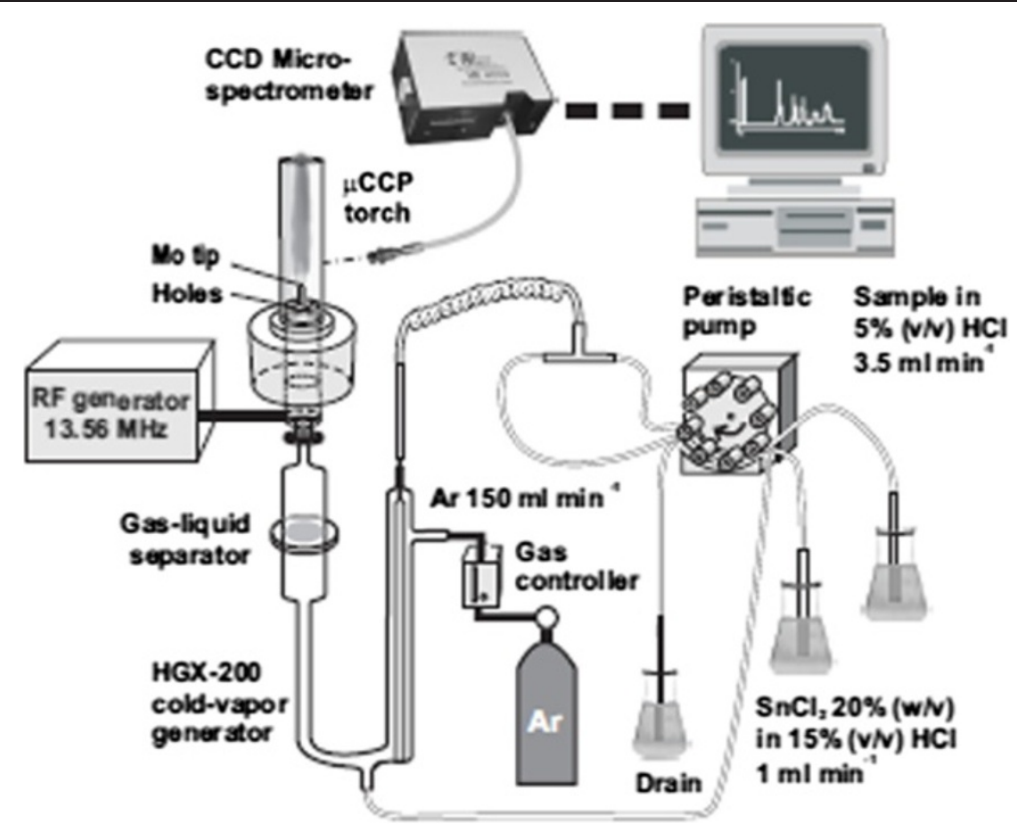

Figure 1 Schematic of the CV- $\mu$ CCP-OES experimental set-up for Hg determination in soil.

microspectrometer and an HGX-200 cold vapor generator. The main characteristics and operating conditions of the $\mathrm{CV}-\mu \mathrm{CCP}-\mathrm{OES}$ system are presented in Additional file 1 . The method is based on the derivatization of $\mathrm{Hg}^{2+}$ from aqueous solutions to $\mathrm{Hg}$ cold vapor following mixing sample solution and $\mathrm{SnCl}_{2}$ acidic solution in the cold vapor generator. The $\mathrm{Hg}$ vapor are purged from solution via an Ar flow ( $150 \mathrm{ml} / \mathrm{min})$ and introduced into the plasma microtorch. The $\mathrm{Hg}$ emission is measured at $253.652 \mathrm{~nm}$. Constructive details related to plasma microtorch and optimal conditions for $\mathrm{Hg}$ signal measurement using the $\mathrm{CV}-\mu \mathrm{CCP}-\mathrm{OES}$ system were previously pre-

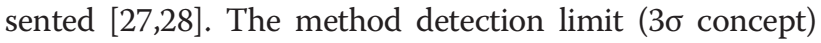
was $4.8 \mu \mathrm{g} / \mathrm{kg} \mathrm{Hg}$, while the practical quantification limit (PQL) in soil samples $14.4 \mu \mathrm{g} / \mathrm{kg}$ [28], 7 times lower than $100 \mu \mathrm{g} / \mathrm{kg}$, considered as the normal level in soil.

Total $\mathrm{Al}, \mathrm{Ba}, \mathrm{Ca}, \mathrm{Cr}, \mathrm{Cu}, \mathrm{Fe}, \mathrm{K}, \mathrm{Li}, \mathrm{Mg}, \mathrm{Mn}, \mathrm{Na}, \mathrm{Sr}$ and $\mathrm{Zn}$ concentrations were determined by ICP-OES using a SpectroCiros ${ }^{\mathrm{CCD}}$ instrument (Kleve, Germany), while water leachable concentration of $\mathrm{Cl}^{-}, \mathrm{NO}_{3}^{-}$and $\mathrm{SO}_{4}^{2-}$ by high performance ion chromatography using a 761 Compact IC Metrohm (Herisau, Switzerland). The pH of soil was measured with a 350i Multiparameter (WTW, Wilheim, Germany) in 1:5 suspension soil:water.

The results obtained in the determination and speciation of $\mathrm{Hg}$ are presented in Table 1, while the chemical composition of soil in Additional file 2.

\section{Statistical analysis}

Statistical data processing was carried out with XLStat Microsoft Excel plug-in (Addinsoft). The distribution maps of the total $\mathrm{Hg}$ and its species in soil were plotted to identify differences between contamination in the impact zone and surroundings. Principal Component Analysis (PCA) and Cluster Analysis (CA) were used to describe the variability in the chemical composition in the soil samples and identify $\mathrm{Hg}$ species of main contribution to the total variability. Principal Component Analysis (PCA) and Cluster Analysis (CA) have been widely used in environmental studies to differentiate between natural and anthropogenic origin of contaminants $[30,31]$. R-mode PCA was applied to assess the weight of the different fractions of $\mathrm{Hg}$, total concentrations of $\mathrm{Hg}$, $\mathrm{Al}, \mathrm{Ba}, \mathrm{Ca}, \mathrm{Cr}, \mathrm{Cu}, \mathrm{Fe}, \mathrm{K}, \mathrm{Li}, \mathrm{Mg}, \mathrm{Mn}, \mathrm{Na}, \mathrm{Sr}, \mathrm{Zn}$, water leachable concentration of anions $\left(\mathrm{Cl}^{-}, \mathrm{SO}_{4}^{2-}\right.$ and $\left.\mathrm{NO}_{3}^{-}\right)$, organic matter and $\mathrm{pH}$ on the variability of chemical composition of soil and fate of $\mathrm{Hg}$. According to the Kaiser criterion only the PC's with eigenvalue $>1.0$ was retained and subjected to varimax rotation. Factor loadings were classified as 'strong,' 'moderate' and 'weak' corresponding to absolute loading values of $>0.75,0.50-0.75$ and in the range $0.30-0.50$, respectively [32]. Cluster Analysis using the Ward's linkage method and Euclidian distances as a measure of similarity was used to group chemical parameters into classes. The Shapiro-Wilk test was used to verify the null hypothesis in relation with the normal distribution of the parameters under study. The Bland and Altman test $[28,33]$ was applied to assess the 3-step sequential extraction of $\mathrm{Hg}$ from soil. Thus the differences (bias) between the sum of the three fractions of $\mathrm{Hg}$ species and $\mathrm{Hg}$ concentration extracted in aqua regia were plotted versus the mean of results. 
Table 1 Content ( $\mathrm{mg} / \mathrm{kg}$ ) of total mercury, water leachable, mobile, semimobile and non-mobile fractions

\begin{tabular}{|c|c|c|c|c|c|c|c|c|c|c|c|c|}
\hline \multirow[t]{2}{*}{ Sample } & \multicolumn{2}{|c|}{ Total mercury in aqua regia } & \multicolumn{2}{|c|}{ Water leachable } & \multicolumn{2}{|c|}{ Mobile fraction } & \multicolumn{2}{|c|}{ Semimobile fraction } & \multicolumn{2}{|c|}{ Non-mobile fraction } & \multicolumn{2}{|c|}{ Fraction sum } \\
\hline & Content $^{a}$ & $s_{r}^{a, b}$ & Content $^{a}$ & $\mathbf{s}_{\mathrm{r}}^{\mathrm{a}, \mathrm{b}}$ & Content $^{a}$ & $s_{r}^{a, b}$ & Content $^{a}$ & $s_{r}^{a, b}$ & Content $^{a}$ & $s_{r}^{a, b}$ & Content $^{c}$ & $s_{r}^{d}$ \\
\hline 1 & 0.72 & 0.01 & 0.008 & 0.001 & 0.034 & 0.001 & 0.39 & 0.01 & 0.23 & 0.01 & 0.65 & 0.01 \\
\hline 2 & 0.095 & 0.006 & 0.005 & 0.001 & 0.008 & 0.001 & 0.083 & 0.002 & 0.003 & 0.001 & 0.094 & 0.002 \\
\hline 3 & 0.46 & 0.01 & 0.008 & 0.001 & 0.040 & 0.001 & 0.26 & 0.01 & 0.12 & 0.01 & 0.42 & 0.01 \\
\hline 4 & 0.47 & 0.01 & 0.013 & 0.001 & 0.053 & 0.002 & 0.39 & 0.01 & 0.041 & 0.001 & 0.48 & 0.01 \\
\hline 5 & 0.24 & 0.01 & 0.007 & 0.001 & 0.012 & 0.001 & 0.22 & 0.01 & 0.022 & 0.002 & 0.25 & 0.01 \\
\hline 6 & 1.99 & 0.02 & 0.0009 & 0.0001 & 0.070 & 0.002 & 1.42 & 0.05 & 0.57 & 0.01 & 2.06 & 0.05 \\
\hline 7 & 0.13 & 0.01 & 0.0090 & 0.0003 & 0.022 & 0.002 & 0.061 & 0.001 & 0.043 & 0.001 & 0.13 & 0.01 \\
\hline 8 & 0.67 & 0.01 & 0.0030 & 0.0001 & 0.0090 & 0.0003 & 0.57 & 0.03 & 0.073 & 0.002 & 0.65 & 0.03 \\
\hline 9 & 1.27 & 0.02 & 0.0060 & 0.0003 & 0.094 & 0.006 & 0.79 & 0.02 & 0.37 & 0.01 & 1.25 & 0.02 \\
\hline 10 & 0.45 & 0.01 & 0.0070 & 0.0003 & 0.0080 & 0.0001 & 0.34 & 0.01 & 0.041 & 0.005 & 0.39 & 0.01 \\
\hline 11 & 0.23 & 0.01 & 0.0003 & 0.0001 & 0.028 & 0.002 & 0.17 & 0.01 & 0.035 & 0.001 & 0.23 & 0.01 \\
\hline 12 & 0.38 & 0.01 & 0.0060 & 0.0002 & 0.019 & 0.001 & 0.33 & 0.01 & 0.022 & 0.001 & 0.37 & 0.01 \\
\hline 13 & 0.35 & 0.01 & 0.0090 & 0.0004 & 0.024 & 0.001 & 0.25 & 0.01 & 0.12 & 0.01 & 0.39 & 0.01 \\
\hline 14 & 0.075 & 0.004 & 0.0040 & 0.0002 & 0.018 & 0.001 & 0.034 & 0.001 & 0.036 & 0.001 & 0.088 & 0.002 \\
\hline 15 & 0.42 & 0.01 & 0.0040 & 0.0002 & 0.022 & 0.001 & 0.25 & 0.01 & 0.14 & 0.01 & 0.41 & 0.01 \\
\hline 16 & 85.5 & 0.6 & 0.017 & 0.001 & 5.60 & 0.04 & 65.6 & 0.5 & 20.2 & 0.1 & 91.4 & 0.5 \\
\hline 17 & 92.6 & 1.7 & 0.025 & 0.002 & 31.20 & 1.00 & 33.3 & 0.2 & 20.0 & 0.3 & 84.5 & 1.1 \\
\hline 18 & 26.3 & 0.3 & 0.37 & 0.02 & 4.78 & 0.16 & 16.7 & 0.2 & 5.20 & 0.02 & 26.7 & 0.3 \\
\hline 19 & 19.3 & 0.2 & 0.0070 & 0.0004 & 0.85 & 0.02 & 20.1 & 0.3 & 1.79 & 0.01 & 22.7 & 0.3 \\
\hline 20 & 114 & 1 & 0.051 & 0.002 & 7.80 & 0.02 & 104 & 1 & 1.76 & 0.04 & 114 & 1 \\
\hline 21 & 35.9 & 2.2 & 0.019 & 0.002 & 0.22 & 0.01 & 42.7 & 2.0 & 0.50 & 0.01 & 43.4 & 2.0 \\
\hline 22 & 54.8 & 0.5 & 1.20 & 0.06 & 9.31 & 0.29 & 31.3 & 0.6 & 6.18 & 0.32 & 46.8 & 0.7 \\
\hline 23 & 0.57 & 0.02 & 0.011 & 0.001 & 0.017 & 0.001 & 0.37 & 0.037 & 0.067 & 0.001 & 0.45 & 0.04 \\
\hline 24 & 0.079 & 0.011 & 0.007 & 0.001 & 0.015 & 0.001 & 0.055 & 0.001 & 0.015 & 0.001 & 0.085 & 0.002 \\
\hline 25 & 16.8 & 0.1 & 0.089 & 0.009 & 0.54 & 0.03 & 15.5 & 0.2 & 2.92 & 0.01 & 19.0 & 0.2 \\
\hline 26 & 0.70 & 0.01 & 0.0040 & 0.0003 & 0.020 & 0.001 & 0.57 & 0.01 & 0.15 & 0.01 & 0.74 & 0.01 \\
\hline 27 & 0.28 & 0.01 & 0.022 & 0.003 & 0.036 & 0.001 & 0.23 & 0.01 & 0.032 & 0.001 & 0.30 & 0.01 \\
\hline 28 & 0.20 & 0.01 & 0.0060 & 0.0003 & 0.017 & 0.001 & 0.12 & 0.01 & 0.090 & 0.001 & 0.23 & 0.01 \\
\hline 29 & 4.44 & 0.01 & 0.097 & 0.004 & 0.21 & 0.01 & 3.27 & 0.01 & 0.24 & 0.01 & 3.72 & 0.02 \\
\hline 30 & 0.41 & 0.01 & 0.011 & 0.001 & 0.012 & 0.001 & 0.36 & 0.01 & 0.046 & 0.003 & 0.42 & 0.01 \\
\hline 31 & 0.12 & 0.01 & 0.0030 & 0.0002 & 0.021 & 0.001 & 0.069 & 0.001 & 0.035 & 0.001 & 0.13 & 0.01 \\
\hline 32 & 0.42 & 0.01 & 0.0070 & 0.0002 & 0.021 & 0.001 & 0.15 & 0.01 & 0.16 & 0.01 & 0.33 & 0.01 \\
\hline 33 & 0.11 & 0.01 & 0.0040 & 0.0001 & 0.014 & 0.001 & 0.072 & 0.001 & 0.021 & 0.001 & 0.11 & 0.01 \\
\hline 34 & 0.84 & 0.01 & 0.0050 & 0.0005 & 0.098 & 0.002 & 0.48 & 0.01 & 0.24 & 0.01 & 0.82 & 0.01 \\
\hline 35 & 20.0 & 0.31 & 0.013 & 0.002 & 0.81 & 0.01 & 18.1 & 0.3 & 0.64 & 0.01 & 19.6 & 0.30 \\
\hline 36 & 6.46 & 0.10 & 0.013 & 0.001 & 0.53 & 0.02 & 4.87 & 0.39 & 0.45 & 0.01 & 5.85 & 0.30 \\
\hline 37 & 8.88 & 0.05 & 0.0010 & 0.0001 & 0.39 & 0.02 & 7.80 & 0.06 & 1.00 & 0.01 & 9.19 & 0.06 \\
\hline 38 & 0.62 & 0.03 & 0.0070 & 0.0003 & 0.042 & 0.002 & 0.51 & 0.01 & 0.12 & 0.01 & 0.67 & 0.01 \\
\hline Mean & 13.1 & & 0.055 & & 1.66 & & 9.78 & & 1.68 & & 13.1 & \\
\hline Variance & 27.8 & & 0.20 & & 5.38 & & 21.3 & & 4.60 & & 27.6 & \\
\hline Median & 0.60 & & 0.007 & & 0.035 & & 0.39 & & 0.13 & & 0.57 & \\
\hline Min & 0.08 & & 0.0003 & & 0.008 & & 0.034 & & 0.003 & & 0.085 & \\
\hline Max & 114 & & 1.20 & & 31.2 & & 104 & & 20.2 & & 114 & \\
\hline
\end{tabular}

${ }^{a}-n=3$ complete dissolution/analysis sequences for each sample.

b-standard deviation of repeatability.

c-sum of mobile, semi-mobile and non-mobile fractions.

${ }^{d}$-pooled standard deviation of sum $s_{\text {pooled }}=\left(s_{1}^{2}+s_{2}^{2}+s_{3}^{2}\right)^{1 / 2}$. 
According to the Bland and Altman test there is no significant bias between two sets of data if the confidence interval of the mean difference contains the zero value and the difference between measurements for each sample lies between the limits of agreement of the results.

\section{Assessment of the fractionation scheme of $\mathrm{Hg}$ species in soil and $\mathrm{CV}-\mu \mathrm{CCP}-\mathrm{OES}$ analytical technique}

The Bland and Altman plots for $\mathrm{Hg}$ content $<1 \mathrm{mg} / \mathrm{kg}$ (24 samples) and $>1 \mathrm{mg} / \mathrm{kg}$ (14 samples) are given in Figure 2. For both concentration ranges the confidence interval of the negative/positive bias towards the sequential extraction included the zero value and the differences between all pairs of data were within the lower and upper limit of agreement. This has demonstrated that the differences between results are random and the 3-step sequential extraction performed in this study is suitable for $\mathrm{Hg}$ speciation in soil. The average recovery of $\mathrm{Hg}$ using the sequential extraction was $100.5 \pm 3.3 \%$ for $95 \%$ confidence interval related to $\mathrm{Hg}$ determined in aqua regia.

Accuracy of $\mathrm{Hg}$ determination by the $\mathrm{CV}-\mu \mathrm{CCP}-\mathrm{OES}$ method was checked by analyzing certified reference materials (CRMs). The results obtained for the analysis of four CRMs of soil (Table 2) show a recovery of $98.3 \pm$ $3.5 \%$ for $\mathrm{Hg}$ determined in soil by the $\mathrm{CV}-\mu \mathrm{CCP}-\mathrm{OES}$ technique.

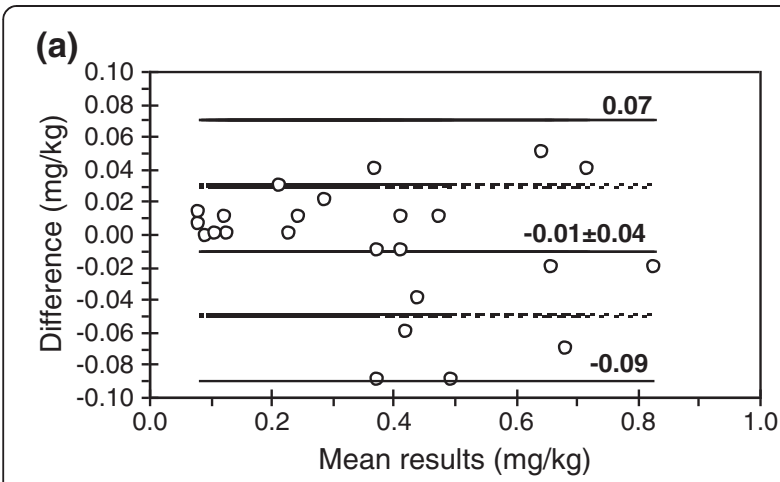

(b)

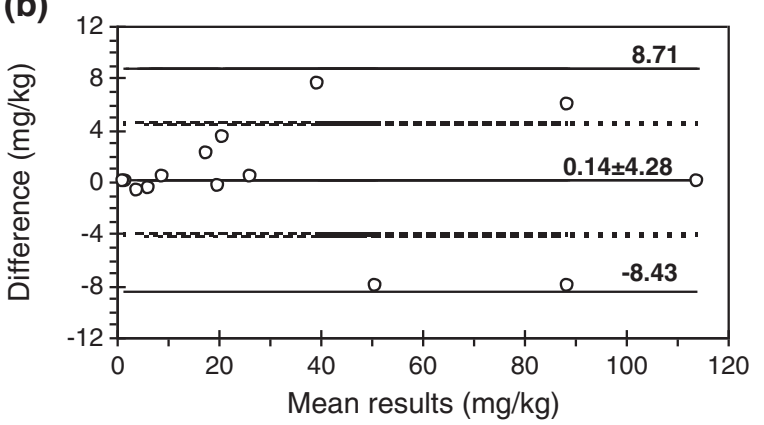

Figure 2 Bland and Altman plots: (a) $<1 \mathrm{mg} / \mathrm{kg} \mathrm{Hg}$ ( $\mathrm{n}=24$ samples); (b) > $1 \mathrm{mg} / \mathrm{kg} \mathrm{Hg}$ ( $\mathrm{n}=14$ samples).
Table 2 Results obtained for $\mathrm{Hg}$ determination $(\mathrm{mg} / \mathrm{kg}$ ) in certified reference materials by $\mathrm{CV}-\mu \mathrm{CCP}-\mathrm{OES}$

\begin{tabular}{lll}
\hline Reference material & Certified value $\pm U^{\mathbf{a}}$ & Found value $\pm U^{\mathbf{a}}(\mathbf{n}=\mathbf{5})$ \\
\hline RTC-CRM048-50G & $28.00 \pm 1.13$ & $27.50 \pm 1.05$ \\
LGC 6135 & $3.2 \pm 0.4$ & $3.0 \pm 0.1$ \\
RTC-CRM 025-050 & $99.8 \pm 31.7$ & $96.7 \pm 0.8$ \\
LGC 6141 & $1.20^{\mathrm{b}}$ & $1.25 \pm 0.06$ \\
\hline
\end{tabular}

${ }^{a}$ Expanded uncertainty for $95 \%$ confidence interval.

${ }^{\mathrm{b}}$ Indicative value.

\section{Results and discussion}

Total $\mathrm{Hg}$ concentration and distribution of fractions

The content of $\mathrm{Hg}$ extracted in aqua regia considered as total, that transferred to water as leachable portion as well as that distributed among the three fractions (mobile, semi-mobile and non-mobile) according to the 3 -step extraction scheme are presented in Table 1. As shown in Table 1, the total $\mathrm{Hg}$ was in the range $0.074-$ $114 \mathrm{mg} / \mathrm{kg}$, while the water leached fraction was much lower, of $0.0003-1.20 \mathrm{mg} / \mathrm{kg}$ corresponding to $0.01-$ $8.8 \%$ of the total. The amount of the mobile fraction was between $0.008-31.2 \mathrm{mg} / \mathrm{kg}$, accounting for $0.5-36.9 \%$ of the total three fractions. The semi-mobile fraction $(0.034-104 \mathrm{mg} / \mathrm{kg} \mathrm{Hg})$ attributed mainly to $\mathrm{Hg}^{0}$ was the major one accounting for $38.6-98.4 \%$. The nonmobile fraction was in the range $0.003-20.2 \mathrm{mg} / \mathrm{kg}$ corresponding to $1.2-48.5 \%$ of the sum of fractions. Shortly, the weight of the three fractions increased in the order mobile $<$ non-mobile $<$ semi-mobile. The pattern is consistent with the low solubility of non-mobile species and low reactivity of $\mathrm{Hg}^{0}$ [34].

The low water-soluble fraction, comparable to that of $0-2.7 \mathrm{mg} / \mathrm{kg}$ (up to $0.8 \%$ of the total $\mathrm{Hg}$ ) reported in the surroundings of a chlor-alkali plant in Netherlands by Bernaus et al. [13] indicated a poor availability of $\mathrm{Hg}$ under weathering processes. The proportion of mobile $\mathrm{Hg}$ species according to EPA-3200 method was also found to be close to values reported by Bernaus et al. $(5.8-18.8 \%$ of the total) under alkaline conditions $(\mathrm{pH}=8.4)$ [13], but much out the range of 0.008 $0.038 \mathrm{mg} / \mathrm{kg}(0.002-0.2 \%$ of the total) extracted in $1 \mathrm{M}$ $\mathrm{NH}_{4} \mathrm{NO}_{3}$ by Garcia-Sanchez et al. [14]. On the other side the semi-mobile $\mathrm{Hg}$ fraction in soil found by us was much higher compared to the concentrations and weight reported by Bernaus et al. [13] around a chlor-alkali plant, Garcia-Sanchez et al.[14] and Malferrari et al. [15] in soil around an abandoned cinnabar mining area. Our results are rather close to those of Kocman et al. [35], who reported a major fraction $(30-60 \%)$ of $\mathrm{Hg}^{0}$ around a cinnabar mine and ore smelting plants. The high semimobile $\mathrm{Hg}$ fraction in soil in the zone under our study was attributed to anthropogenic input as $\mathrm{Hg}^{0}$ of low reactivity and difficult to be converted into water available, mobile or non-mobile species. In fact, in some soil 
samples collected from the former industrial zones the presence of metallic $\mathrm{Hg}$ was visually identified. On the other hand $\mathrm{Hg}^{0}$ exhibits high volatility at ambient temperature and can be taken up via leaves thus increasing the $\mathrm{Hg}$ content in biomass. Several studies emphasized this contamination route in plant specimens growing in soil with high $\mathrm{Hg}^{0}$ concentration $[14,36]$. The non-mobile fraction of $\mathrm{Hg}$ found by us was lower than that reported by Bernaus et al. [13] who found this fraction as major (36.0-90.7\% of the total). Corroboration of our results with literature data suggests that the fraction distribution, fate of anthropogenic $\mathrm{Hg}$ and its persistence in soil are governed by industry type and associated species released in the environment.

\section{Spatial variability of total mercury distribution in soil}

In order to highlight the spatial variability of soil contamination, the punctual $\mathrm{Hg}$ concentrations were compared to normal content, alert and intervention thresholds for soil in sensitive areas given in the quality guideline [37]. The alert threshold corresponds to the concentration which, if exceeded, imposes an investigation with respect to the individual case in question and is designed to alert authorities about a potential environmental impact. The intervention threshold is related to the concentration of a pollutant which shall enforce risk assessment studies to reduce concentrations by decontamination. The concentrations of total $\mathrm{Hg}$ in soil over the entire investigated area were related to reference values for sensitive areas, as all industrial facilities have been closed and soil decontamination is in question in order to return into urban circuit. The analyzed soil samples were classified in four groups based on the $\mathrm{Hg}$ contamination factor $\left(\mathrm{C}_{\mathrm{f}}\right)$ computed by dividing the $\mathrm{Hg}$ concentration by its normal value in soil $[30,38]$. The spatial variability of total $\mathrm{Hg}$ in soil using punctual concentrations and grouping of sites according to $C_{f}$ values are given in Figure 3. Only three sites $(2,14$ and 24) are classified as non-polluted, while the most sites exhibit a low contamination with $\mathrm{C}_{\mathrm{f}}$ between 1.1-7.2. The spatial distribution shows that in the area of the former chloralkali plant (sites 16-22) the soil is highly contaminated with $\mathrm{Hg}\left(\mathrm{C}_{\mathrm{f}}\right.$ 193-1136). In the same time, the distribution map reveals an extension of $\mathrm{Hg}$ contamination well beyond the area of the former chlor-alkali plant. Thus, elevated $\mathrm{Hg}$ contents were found in soil collected from sites $25\left(C_{f} 169\right), 29\left(C_{f} 44\right), 35-37\left(C_{f} 65-200\right)$, relatively far from the former pollution source. The contamination of these sites is rather the result of their use as landfills 40-50 years ago than of atmospheric pollution via $\mathrm{Hg}$ vapor diffuse transportation by the air currents. Sites 6 and 9 located in the center of the town fall in the category of those medium polluted $\left(\mathrm{C}_{\mathrm{f}} 13-20\right)$ leading to the idea that the influence of urban traffic on soil contamination should also be considered. Anyway, variability of total mercury distribution and high contamination of areas outside the pollution core are consistent with other works $[13,14,16]$ which report large differences among collection points separated by only a few hundred meters.

\section{Spatial variability of water leachable mercury distribution in soil}

Besides total mercury, another useful criterion in this study for assessing the potential risk of contamination of the environment was the water available mercury fraction. The reason is that even small concentrations of total mercury in soil may result in a great water mobility posing a risk to the environment. A certain content of water available $\mathrm{Hg}$ in soil may qualify it as hazardous

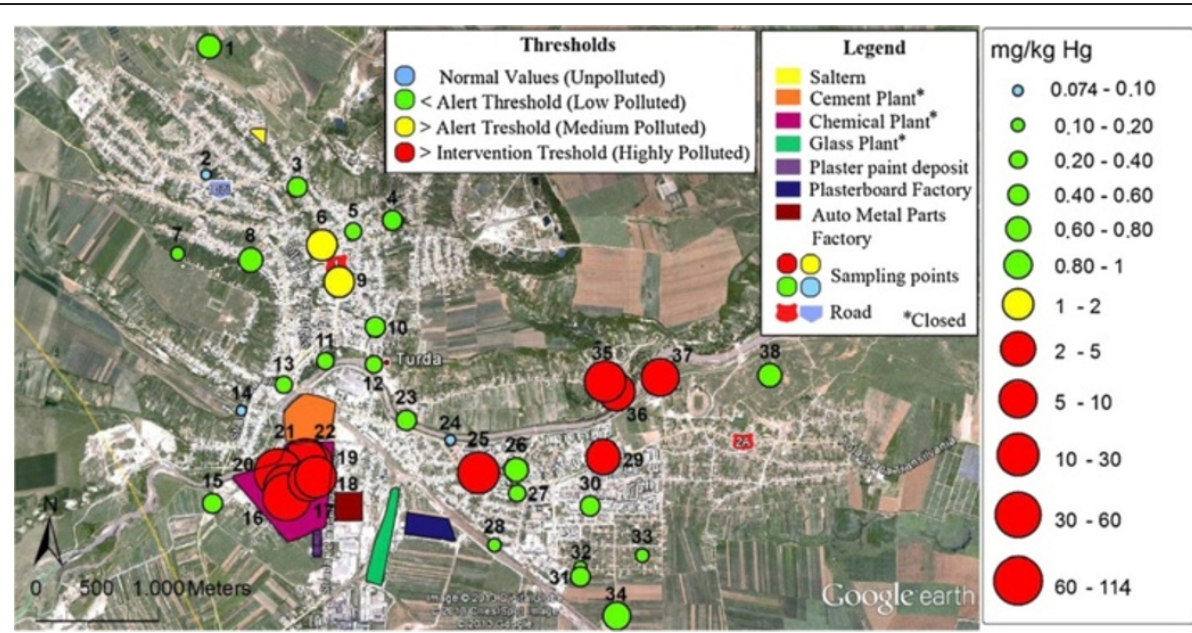

Figure 3 Spatial variability of total $\mathrm{Hg}$ in soil and comparison with soil quality guideline (normal content: $0.1 \mathrm{mg} / \mathrm{kg}$; alert threshold: 1 $\mathrm{mg} / \mathrm{kg}$ and intervention threshold: $2 \mathrm{mg} / \mathrm{kg}$ ). 
waste according [39]. Waste is classified as inert, nonhazardous or hazardous if the $\mathrm{Hg}$ water leachable fraction is $<0.003 \mathrm{mg} / \mathrm{kg},<0.05 \mathrm{mg} / \mathrm{kg}$ and $>0.05 \mathrm{mg} / \mathrm{kg}$, respectively. The spatial variability of the water leachable mercury content at a liquid-to-solid ratio of $2 \mathrm{l} / \mathrm{kg}$ and grouping of sites according to waste classification criteria are presented in Figure 4a. The weight of this fraction related to that extracted in aqua regia is shown in Figure $4 \mathrm{~b}$. The water available fraction increased but generally its weight decreased with total $\mathrm{Hg}$ increased. According to Figure 4a, soil in the residential area was found to be non/low polluted in terms of total $\mathrm{Hg}$ content and in the same time complied with the leachability limit of non-hazardous waste. Only in 4 collection sites, of which 3 situated in the residential area, soil matched criteria for inert waste with no contamination risk. In samples collected from the industrial area (sites 1622 ) and outside the perimeter (sites 25,29) soil was found to be highly polluted in terms of total $\mathrm{Hg}$ content and the leachability limit of $\mathrm{Hg}$ in hazardous waste was also surpassed. As a consequence the soil in these sites exhibits significant risk of water contamination under certain climatic conditions. On the other hand, the soils from sites 35,36 and 37, found also as strongly contaminated from the point of view of total $\mathrm{Hg}$, exhibited low water leachability of $\mathrm{Hg}$ species and were categorized as non-hazardous or even inert waste.

\section{Spatial variability of mobile, semi-mobile and non-mobile Hg species}

The distribution maps of spatial variability of mobile, semi-mobile and non-mobile $\mathrm{Hg}$ species concentrations in soil together with the corresponding proportion related to their sum are presented in Figure 5 and Figure 6. Similar patterns with high spatial variability were observed for all three fractions. The measured fractions were the highest in soil with high total $\mathrm{Hg}$ content in the former Chemical Plant area as well as in samples collected from sites 25, 29 and 35 - 37. The fraction of semi-mobile $\mathrm{Hg}$ species in soil associated mainly to $\mathrm{Hg}^{0}$ was dominant throughout the collection area (Figure $5 \mathrm{~b}$ )

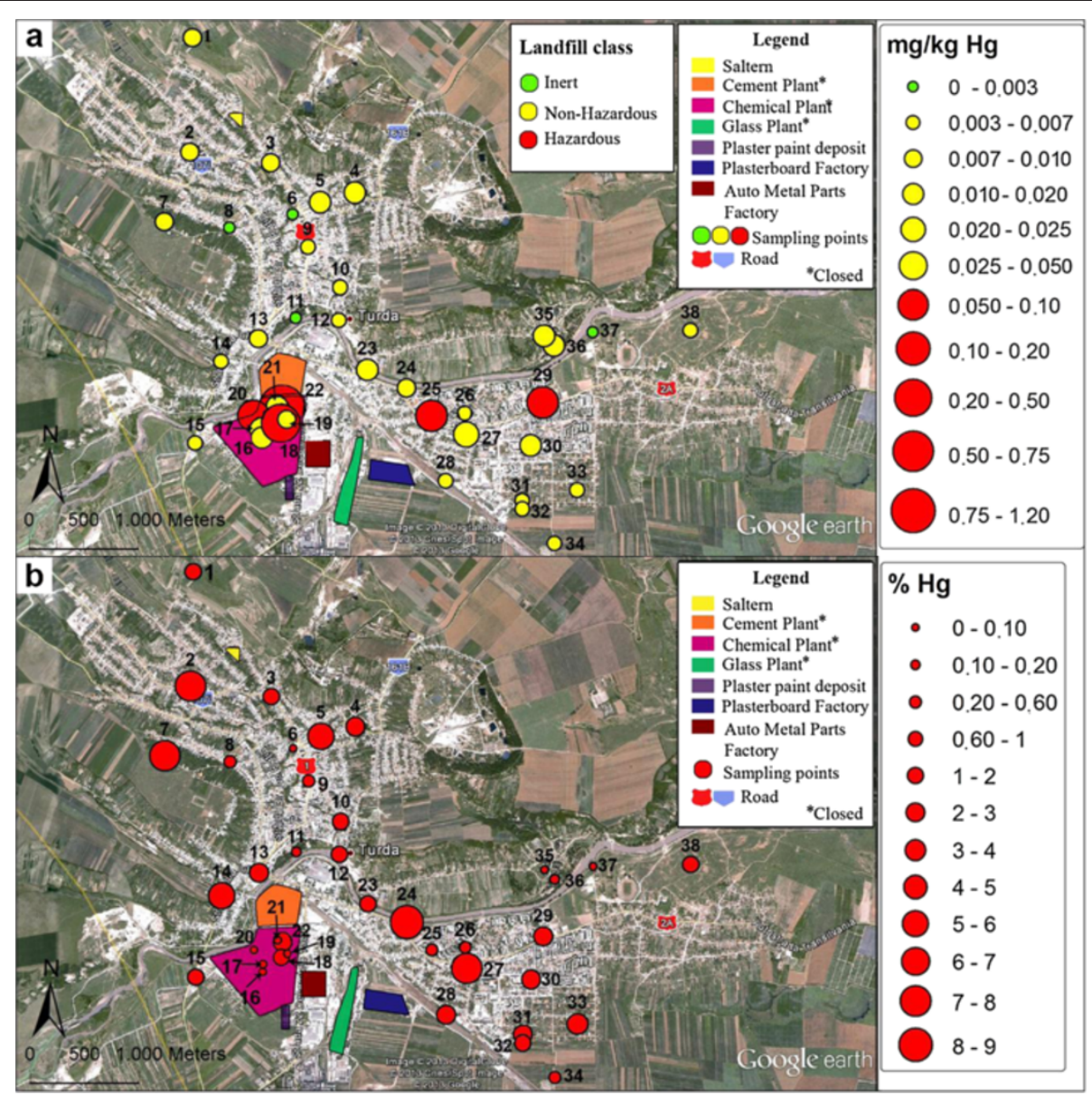

Figure 4 Spatial distribution of the water leachable $\mathbf{H g}$. $\mathbf{a}$. Leached content (mg/kg); b. Weight (\%) related to total Hg extracted in aqua regia. Comparison with leaching limit values for granular waste $(\mathrm{mg} / \mathrm{kg}$ ): inert $<0.003$; non-hazardous $<0.05$ and hazardous $>0.05$. 


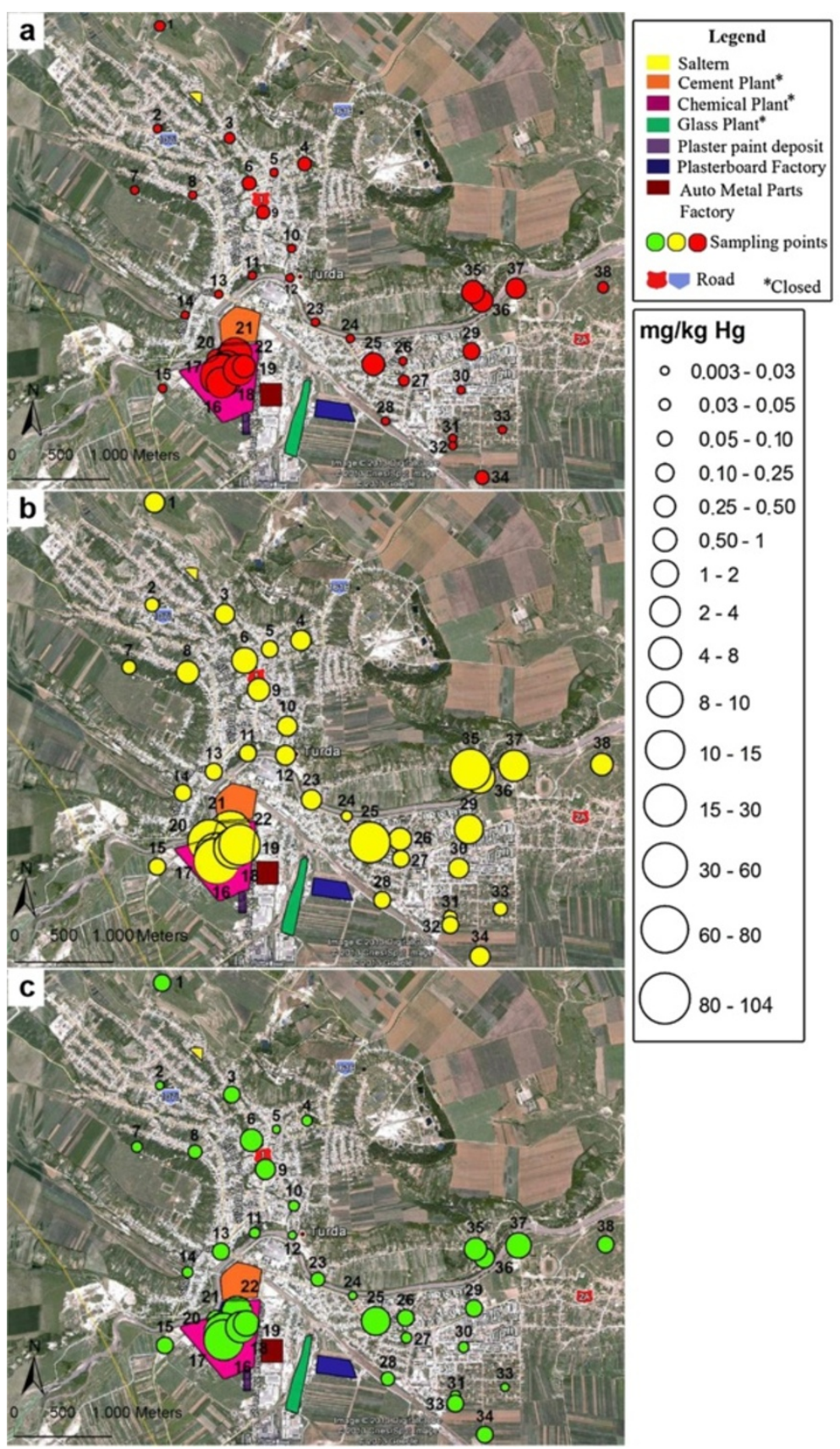

Figure 5 Spatial distribution ( $\mathrm{mg} / \mathrm{kg}$ ) of mobile (a), semi-mobile (b) and non-mobile $\mathrm{Hg}$ species (c).

with quite uniform distribution in terms of weight of the fractions sum (Figure 6b). This behavior was consistent with the important input of anthropogenic $\mathrm{Hg}^{0}$ originating from the industrial zone. The proportion of the semi-mobile fraction decreased on the account of the non-mobile species (Figure 6c) retained by the soil components. Also, the weights of the mobile (Figure 6a) and non-mobile (Figure 6c) $\mathrm{Hg}$ fractions were higher in soils from the residential area with low content of total $\mathrm{Hg}$.

\section{Chemical characterization of soil}

Several characteristics of soil besides $\mathrm{Hg}$ related to possible contamination in this area are presented in Additional file 2. Some of these parameters could influence the fate of $\mathrm{Hg}$ in soil. The $\mathrm{pH}$ of soil exhibited a low variability in the slightly basic range $(7.7-9.3)$. The content of organic carbon varied from $0.13 \%$ (site 20 in the industrial zone) to $2.78 \%$ (site 1 outside the town). The concentration of $\mathrm{Cr}$ was at the level of the detection limit in ICP-OES $(2 \mathrm{mg} / \mathrm{kg})$ in 4 soil samples. The 


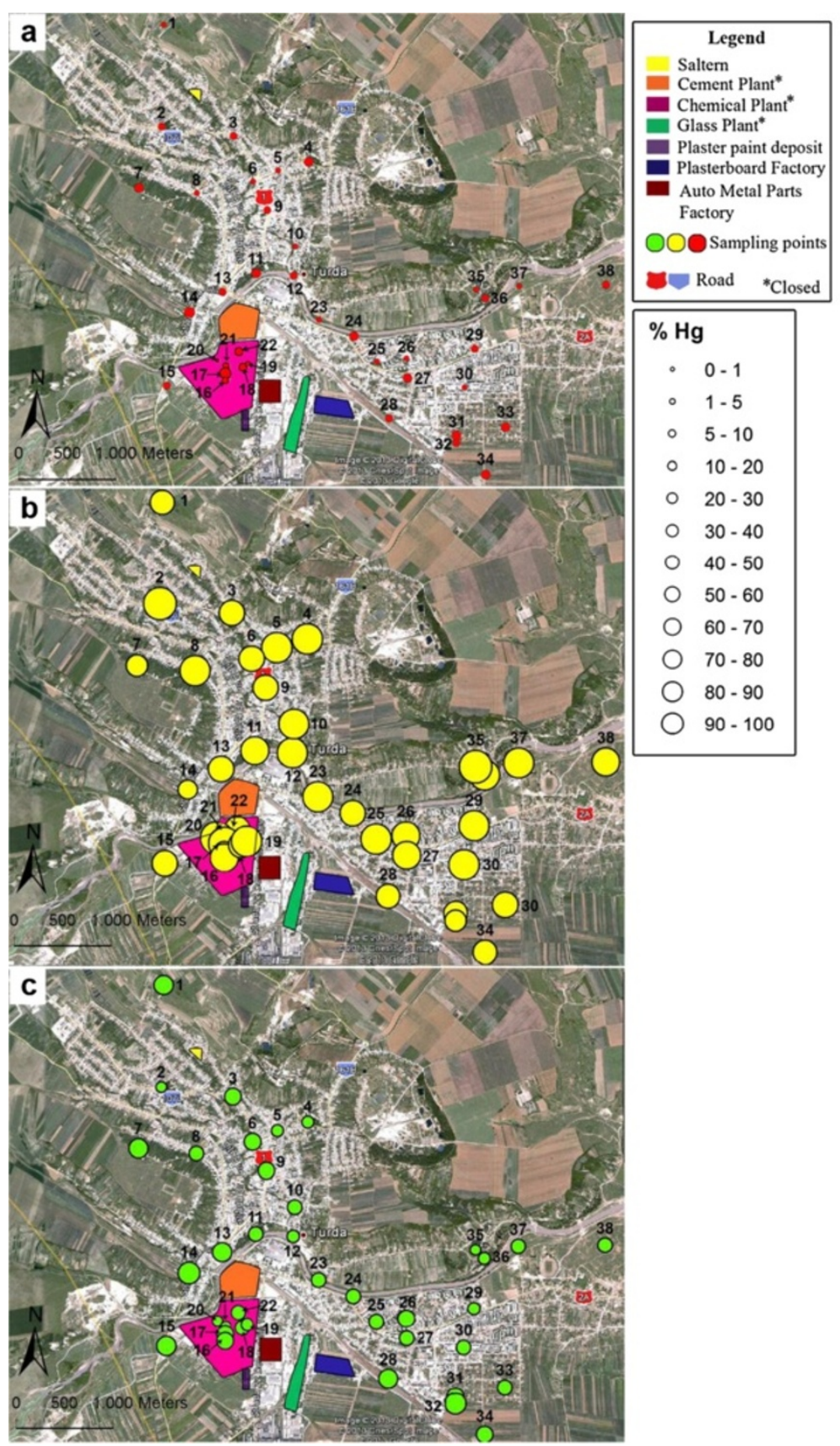

Figure 6 Spatial distribution in weight (\%) of mobile (a), semi-mobile (b) and non-mobile $\mathrm{Hg}$ species (c) related to the sum of fractions.

priority hazardous metals $(\mathrm{Cd}, \mathrm{Pb}$ and $\mathrm{Ni})$ and $\mathrm{Co}$ were not taken under consideration for soil characterization as their concentrations were below the detection limits $(\mathrm{mg} / \mathrm{kg}): 1.70 \mathrm{Cd}, 50 \mathrm{~Pb}, 12 \mathrm{Ni}$ and $1.70 \mathrm{Co}$ in any samples. At these concentration levels ICP-OES does not provide the precision necessary for quantification (at least 10\%). It has been found a considerable soil contamination in the industrial area (sites 16-22) with $\mathrm{Cu}$ and $\mathrm{Zn}$, which exceed occasionally the alert threshold
(200 mg/kg Cu and $600 \mathrm{mg} / \mathrm{kg} \mathrm{Zn)} \mathrm{according} \mathrm{to} \mathrm{[37].}$ Copper and $\mathrm{Zn}$ in these site are of anthropogenic origin associated to production of $\mathrm{Cu}$ pesticides and $\mathrm{Zn}$ salts. In specific locations, outside the industrial perimeter, the alert threshold for $\mathrm{Zn}(300 \mathrm{mg} / \mathrm{kg})$ and the intervention threshold for $\mathrm{Cu}$ (sites 34-38) were exceeded as the result of the high input of waste deposition in the past. On the other hand, elevated concentrations of $\mathrm{K}, \mathrm{Ca}, \mathrm{Na}$ and $\mathrm{Cl}^{-}$originating from $\mathrm{K}$ salt production and calcium 
hypochlorite produced in the past and $\mathrm{NaCl}$ as raw material were found.

\section{Application of PCA and CA to evaluate the variability of soil chemical composition}

Among the parameters used to characterize the chemical composition of soil only $\mathrm{pH}$, total organic carbon (TOC), $\mathrm{Ba}$ and $\mathrm{Sr}$ exhibited normal distribution according to the Shapiro-Wilk test for 95\% confidence level. However the PCA approach is not significantly affected by the lack of normal distribution. The varimax rotated loadings of 7 PC's with eigenvalue $>1$ explaining $79.2 \%$ of soil chemical variability are presented in Table 3 . Mercury or its species as soil characteristics belongs to 3 of the 7 PCs, which totals $41 \%$. The first factor (PC1) accounting for $22.0 \%$ of the total variance of soil chemical composition was attributed mainly to total $\mathrm{Hg}$, mobile, semi-mobile and non-

Table 3 Factor loadings after Varimax rotation describing variability of soil chemical composition

\begin{tabular}{|c|c|c|c|c|c|c|c|}
\hline & PC1 & PC2 & $P C 3$ & PC4 & PC5 & PC6 & PC7 \\
\hline $\mathrm{THg}$ & 0,945 & $-0,058$ & 0,097 & 0,082 & 0,068 & 0,029 & $-0,044$ \\
\hline $\mathrm{L} \mathrm{Hg}$ & 0,257 & $-0,096$ & 0,585 & $-0,026$ & 0,242 & $-0,244$ & 0,407 \\
\hline $\mathrm{M} \mathrm{Hg}$ & 0,794 & $-0,028$ & 0,041 & 0,105 & 0,041 & $-0,213$ & 0,096 \\
\hline $\mathrm{Sm} \mathrm{Hg}$ & 0,831 & $-0,054$ & 0,105 & 0,076 & 0,056 & 0,116 & $-0,149$ \\
\hline $\mathrm{N}-\mathrm{M} \mathrm{Hg}$ & 0,839 & $-0,053$ & $-0,063$ & $-0,023$ & 0,162 & 0,195 & 0,173 \\
\hline $\mathrm{pH}$ & $-0,137$ & $-0,042$ & 0,254 & $-0,158$ & $-0,155$ & $-0,144$ & $-0,659$ \\
\hline TOC & $-0,118$ & 0,223 & 0,129 & $-0,305$ & $-0,243$ & $-0,112$ & 0,612 \\
\hline $\mathrm{Al}$ & $-0,216$ & 0,693 & $-0,323$ & 0,083 & $-0,093$ & 0,315 & 0,174 \\
\hline $\mathrm{Ba}$ & 0,079 & 0,187 & $-0,131$ & $-0,088$ & $-0,123$ & 0,846 & $-0,041$ \\
\hline $\mathrm{Ca}$ & 0,227 & 0,130 & 0,860 & 0,019 & 0,146 & 0,045 & $-0,006$ \\
\hline $\mathrm{Cr}$ & $-0,206$ & 0,030 & $-0,100$ & $-0,856$ & $-0,196$ & 0,047 & $-0,043$ \\
\hline $\mathrm{Cu}$ & 0,460 & $-0,117$ & $-0,009$ & 0,329 & $-0,009$ & 0,625 & 0,163 \\
\hline $\mathrm{Fe}$ & 0,403 & 0,157 & $-0,699$ & $-0,195$ & $-0,150$ & 0,288 & 0,089 \\
\hline K & $-0,184$ & 0,805 & 0,185 & $-0,227$ & $-0,061$ & 0,158 & 0,061 \\
\hline $\mathrm{Li}$ & 0,066 & 0,731 & 0,206 & 0,144 & $-0,100$ & 0,000 & 0,114 \\
\hline $\mathrm{Mg}$ & $-0,015$ & 0,798 & $-0,237$ & 0,018 & $-0,047$ & $-0,178$ & $-0,086$ \\
\hline $\mathrm{Mn}$ & $-0,049$ & $-0,057$ & $-0,654$ & $-0,121$ & $-0,151$ & $-0,047$ & 0,137 \\
\hline $\mathrm{Na}$ & 0,070 & $-0,020$ & 0,181 & 0,074 & 0,946 & $-0,107$ & $-0,005$ \\
\hline $\mathrm{Sr}$ & 0,075 & 0,649 & 0,498 & 0,345 & 0,107 & 0,135 & $-0,073$ \\
\hline $\mathrm{Zn}$ & $-0,064$ & 0,057 & 0,102 & 0,646 & $-0,151$ & 0,616 & $-0,065$ \\
\hline $\mathrm{Cl}^{-}$ & 0,009 & $-0,057$ & 0,092 & 0,053 & 0,959 & $-0,132$ & $-0,043$ \\
\hline $\mathrm{NO}_{3}^{-}$ & 0,023 & 0,088 & 0,046 & 0,860 & 0,063 & 0,036 & $-0,044$ \\
\hline $\mathrm{SO}_{4}^{2-}$ & 0,458 & $-0,071$ & 0,017 & 0,063 & 0,690 & 0,326 & 0,170 \\
\hline Variance (\%) & 22.0 & 15.1 & 14.3 & 9.7 & 7.8 & 5.6 & 4.7 \\
\hline \multicolumn{8}{|c|}{ 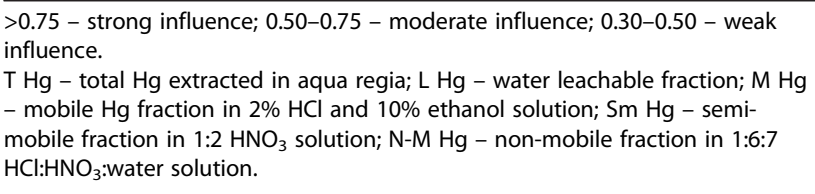 } \\
\hline
\end{tabular}

mobile $\mathrm{Hg}$ fractions with strong influence. Other parameters, like $\mathrm{Cu}, \mathrm{Fe}$ and $\mathrm{SO}_{4}^{2-}$ had weak influence. The $\mathrm{Hg}$ water leacheable fraction exhibited no influence of PC1 consistent with a different origin from the other $\mathrm{Hg}$ species. We may assume that the leachable $\mathrm{Hg}$ species exists as $\mathrm{CH}_{3} \mathrm{Hg}^{+}$produced from inorganic $\mathrm{Hg}^{2+}$ species by sulfate reducing bacteria under anoxic condition. The process is facilitated by the increase of the concentration of $\mathrm{Hg}^{2+}$ available species as well as of $\mathrm{SO}_{4}^{2-}$ concentration up to $0.11 \mathrm{~g} / \mathrm{kg}$ [40]. In the case under study, in sites with high contamination this process is inhibited. Bernaus et al. [13] have found a positive correlation of $\mathrm{Hg}$ with $\mathrm{Cu}$ and $\mathrm{Ni}$ attributed to formation of solid solutions within the same crystalline structure. The correlation of $\mathrm{Hg}$ with $\mathrm{Cu}$ was also found by us but it was not verified by the $\mathrm{X}$ ray diffraction. Similar to $\mathrm{Cu}$, a correlation of $\mathrm{Fe}$ with $\mathrm{Hg}$ species was identified so that the retention of mobile $\mathrm{Hg}$ species by adsorption on Fe oxy-hydroxide could not be neglected as remarked by Kinniburg and Jackson [41]. The presence of $\mathrm{SO}_{4}^{2-}$ in this $\mathrm{PC}$ is consistent with its association with $\mathrm{Hg}$ mobile fraction in agreement with the results of Bernaus et al. [13], who reported that in the surroundings of a chlor-alkali plant $\mathrm{HgSO}_{4}$ was the main mobile species. Chloride and $\mathrm{NO}_{3}^{-}$seem to play no role in the generation of $\mathrm{Hg}$ mobile species. The lake of correlation between $\mathrm{Hg}$ species on the one hand and some natural components of soil having normal distribution (TOC, $\mathrm{pH}, \mathrm{Ba}$ and $\mathrm{Sr}$ ) on the other hand has indicated that the origin of $\mathrm{Hg}$ is mainly anthropogenic $\left(\mathrm{Hg}^{0}\right)$. Generally under natural conditions more that $97 \%$ of the total $\mathrm{Hg}$ in soil is bound to organic matter or precipitated as sulfide [12] but this pattern did not fit to our study. PC2 (15.1\%) explains the influence of aluminosilicates on the variability of the chemical composition of soil. The absence of the Hg species in this PC is in agreement with the higher affinity of $\mathrm{Hg}$ for acidic minerals compared to basic minerals as demonstrated by $\mathrm{Hg}$ determinations in such samples [42].

Two factors, PC3 (14.1\%) and PC7 (4.7\%), were assigned to water leachable fraction of $\mathrm{Hg}$. The high positive loading of $\mathrm{Ca}$ in $\mathrm{PC} 3$ results from an anthropogenic input via $\mathrm{Ca}$ hypochlorite produced in the past, which enhances $\mathrm{Hg}$ mobility. It is well known the use of Ca hypochlorite for the remediation of $\mathrm{Hg}$ contaminated soil [43] but this strategy was not used in the zone studied by us. Iron and $\mathrm{Mn}$ as effective sorbents for $\mathrm{Hg}^{2+}$ have a moderate negative influence in $\mathrm{PC} 3$ on water mobilization of $\mathrm{Hg}$ [41].

PC7 (4.8\%) shows the influence of two natural characteristics of soil (organic matter and $\mathrm{pH}$ ) on the chemical composition and water leachable $\mathrm{Hg}$ species, and suggests the presence of $\mathrm{Hg}$ as organic water soluble species. Their weight tends to increase with organic matter content and to decrease as $\mathrm{pH}$ increases. 
The forth principal component (PC4) accounting for $9.7 \%$ variability reflects a strong influence of $\mathrm{Cr}$ as organic species of natural origin and $\mathrm{Zn}$ as nitrate of anthropogenic source on the chemical composition of soil. On the other hand these parameters have no influence on $\mathrm{Hg}$ species.

The fifth factor (PC5) explaining 7.8\% of the total variance was assigned to the influence of $\mathrm{Na}$ salts (chloride and sulfate) of anthropogenic origin on the soil chemical composition. The strong factor loadings of $\mathrm{Na}$ and $\mathrm{Cl}^{-}$ and the moderate one of sulfate suggest the presence of $\mathrm{Na}$ mainly as chloride originating from the raw material used in the past. The highest concentrations of these species were found in water leachate of soil from the industrial area. Chloride has no influence on the mobilization of $\mathrm{Hg}$ species in agreement with a study of Bernaus et al. [13] who reported a random relationship between $\mathrm{Hg}$ and $\mathrm{Cl}^{-}$in soil in the surroundings of a chlor-alkali plant.

PC6 (5.6\%) describes the influence of the heavy metals $(\mathrm{Cu}$ and $\mathrm{Zn})$ of anthropogenic origin on the chemical composition of soil. The highest concentrations of these metals were found in soil from the perimeter of the former Chemical Plant and in the zone of the former waste landfills. One can observe the positive correlation between these elements and $\mathrm{SO}_{4}^{2-}$. The coexistence of these elements together with $\mathrm{Ba}$ in the same PC has been previously remarked in the case study on river sediment in an area under the impact of non-ferrous ore mining [30].

Two-dimensional plots of the first three PCs made it possible to identify 3 groups of sites on the basis of all parameters under study (Additional file 3). The first group encompasses sites (16-22) in the area of the former Chemical Plant, where soils have been found highly contaminated with $\mathrm{Hg}$ and categorized as hazardous waste. To the second group belong sites (35-37) in the area of the former waste landfills also found as highly contaminated with $\mathrm{Hg}$ but here the soil was categorized as non-hazardous waste. The third, largest group contains Hg low-contaminated sites where soil corresponds to non-hazardous waste criteria. The same pattern is true considering only the parameters related to Hg species (Additional file 4).

The dendrogram in Figure 7 presents grouping of soil characteristics in three main clusters. Cluster $\mathrm{C} 1$ with 2 sub-clusters contains parameters of dominant influence on soil and confirms the anthropogenic origin of $\mathrm{Hg}$ by grouping together total, mobile, semi-mobile and nonmobile $\mathrm{Hg}$ species. One can remark the association between $\mathrm{Cu}$ and $\mathrm{SO}_{4}^{2-}$ following the anthropogenic input as $\mathrm{CuSO}_{4}$ used as raw material to obtain copper fungicide. The second sub-cluster of $\mathrm{C} 1$ indicates the presence of $\mathrm{Na}$ as $\mathrm{NaCl}$ and the influence of $\mathrm{Ca}$ as hypochlorite on water leachability of $\mathrm{Hg}$. The second cluster (C2) groups in two sub-clusters elements usually present in aluminosilicates and $\mathrm{Zn}$ as nitrate as previously suggested by PCA. Cluster C3 contains 2 sub-clusters, one of which suggesting $\mathrm{Cr}$ binding to organic matter.

\section{Conclusions}

A case study on $\mathrm{Hg}$ contamination in the surroundings of a former chlor-alkali plant closed more than 15 years ago was conducted. Determination of total $\mathrm{Hg}$ content, water leachable, mobile, semi-mobile and non-mobile $\mathrm{Hg}$ species was performed using a novel analytical technique based on CV- $\mu$ CCP-OES. Results have shown a high spatial variability of contamination with $\mathrm{Hg}$ species,

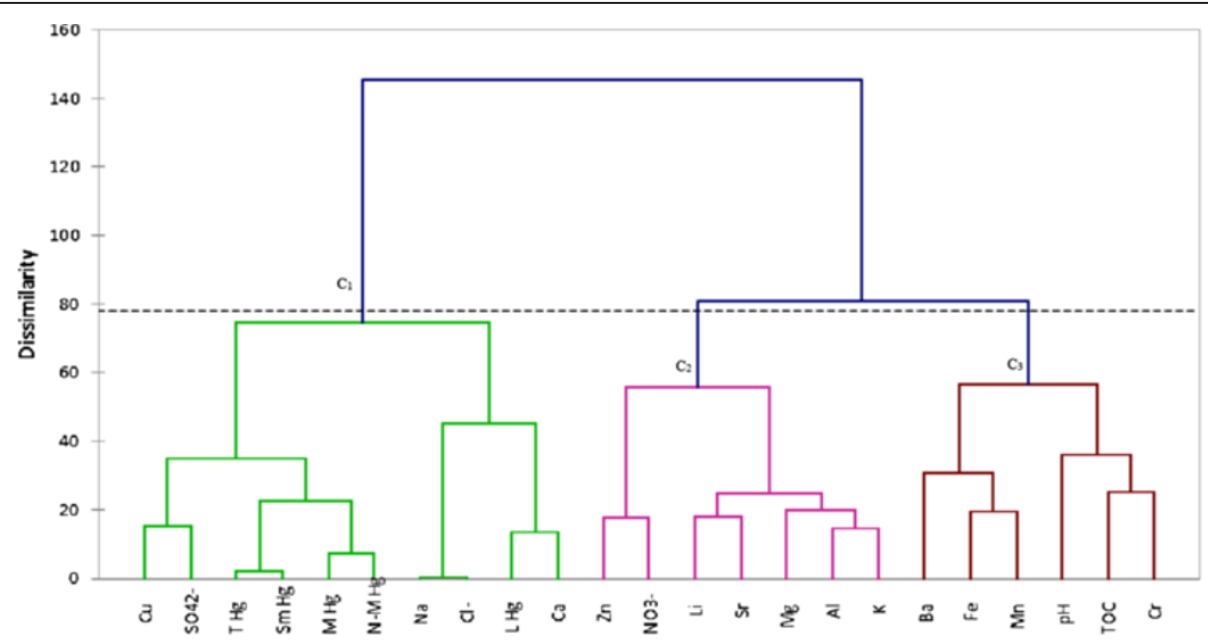

Figure 7 Dendrogram showing the clustering of soil characteristics. $\mathrm{T} \mathrm{Hg}$ - total $\mathrm{Hg}$ extracted in aqua regia; L Hg - water leachable fraction; $\mathrm{M} \mathrm{Hg}$ - mobile $\mathrm{Hg}$ fraction in $2 \% \mathrm{HCl}$ and $10 \%$ ethanol solution; $\mathrm{Sm} \mathrm{Hg}$ - semi-mobile fraction in 1:2 $\mathrm{HNO}_{3}$ solution; $\mathrm{N}-\mathrm{M} \mathrm{Hg}$ - non-mobile fraction in 1:6:7 $\mathrm{HCl} \mathrm{HNO}_{3}$ :water solution. 
of which the $\mathrm{Hg}^{0}$ semi-mobile fraction was the main form. The Principal Component Analysis applied on standardized data related to $\mathrm{Hg}$ species and chemical composition of soil revealed the main contributors to the variability and the dominant factors governing the fate of $\mathrm{Hg}$ species in soil. Total Hg, semi-mobile, nonmobile and mobile species were observed to have the greatest influence on soil chemical composition variability. The influence of the $\mathrm{Hg}$ water soluble fraction was weak, although within the perimeter of the former plant and waste landfills soil could be regarded as a hazardous waste according to the test of leachability. PCA also revealed a different origin of the $\mathrm{Hg}$ water soluble fraction, mainly bind to organic matter and controlled by soil $\mathrm{pH}$, $\mathrm{Ca}$, Mn and $\mathrm{Fe}$ content. Among anions, only sulfate plays a significant role in binding $\mathrm{Hg}^{2+}$ species as soluble inorganic compounds. Aluminosilicates, $\mathrm{Zn}$ and $\mathrm{Cr}$ compounds play no role in the retention of $\mathrm{Hg}$ species, while $\mathrm{Cu}$ compounds a minor role. Plotting data with respect to the first three PCs is useful to identify the spatial variability of soil contamination with $\mathrm{Hg}$ and allows grouping sites with similar contamination factors. Cluster analysis of soil characteristics has confirmed the hypothesis of the anthropogenic origin of $\mathrm{Hg}$ in the area contaminated by the chlor-alkali industry by grouping $\mathrm{Hg}$ species in the same cluster, distinct from that including natural components of soil such as aluminosilicates. Cluster analysis has also shown soil contamination with $\mathrm{Cu}$ as sulfate, $\mathrm{Zn}$ as nitrate and the presence of $\mathrm{NaCl}$. The approach based on speciation and statistical interpretation of data such as that used by us in this case study could be of interest to evaluate other areas of similar contamination. The method based on the proposed miniaturized instrumentation has found to be suitable for $\mathrm{Hg}$ determination.

\section{Additional files}

\section{Additional file 1: Characteristics and working conditions of the CV- $\mu C C P-O E S$ analytical system.}

Additional file 2: Chemical characterization of soil.

Additional file 3: Two dimensional plot of PCs considering all investigated parameters of soil.

Additional file 4: Two dimensional plot of PCs considering $\mathrm{Hg}$ parameters of soil.

\section{Authors' contributions}

TF - designed the study and coordinated the preparation of the manuscript, interpreted the results of chemical analysis and multivariate statistical analysis (PCA and CA), and co-worked on the Hg determination by cold vapor capacitively coupled microplasma optical emission spectrometry; MP - co-worked on the soil sample analysis by optical emission spectrometry and performed the data comparison using the Bland and Altman test; AIM - performed soil sample collection, measurements of $\mathrm{pH}$ and organic matter and co-worked on sample preparation for $\mathrm{Hg}$ determination; BPP - coworked on sample preparation and analysis by cold vapor capacitively coupled microplasma optical emission spectrometry and prepared the manuscript graphics; SB - co-worked on sample preparation and analysis by cold vapor capacitively coupled microplasma optical emission spectrometry; MF - coworked on sample preparation and measurements of $\mathrm{pH}$ and organic matter in soil samples. All authors read and approved the final manuscript.

\section{Authors' information}

TF is associate professor of instrumental analysis at the University Babes-Bolyai, Faculty of Chemistry and Chemical Engineering, Cluj-Napoca, Romania. His research field includes the development of analytical methods by optical emission spectrometry in inductively or capacitively coupled plasma sources for the determination of priority hazardous elements in environmental samples and materials. He has also interests in the development of miniaturized analytical instrumentation based on plasma microtorches for on-site analysis.

MP is associate professor of instrumental analysis at the University Babes-Bolyai, Faculty of Chemistry and Chemical Engineering, Cluj-Napoca, Romania. Her area of interests covers the development of analytical methods by atomic spectrometry, toxicological analysis, and quality control and quality assurance in chemical analysis.

AIM is Researcher at Research Institute for Analytical Instrumentation, Cluj-Napoca and PhD student at University Babes-Bolyai, Cluj-Napoca, Romania. His scientific interests relate to monitoring of the priority hazardous metals in environmental samples and different materials, as well as development of analytical methods using instrumentation based on plasma microtorches. MF is Researcher at Research Institute for Analytical Instrumentation, Cluj-Napoca, Romania. Her scientific interest relates to the development of environmental sample preparation methods.

BPP is engineer and Master student at University Babes-Bolyai, Cluj-Napoca, Romania, with expertise in environmental quality control and depollution techniques.

SB is Master student at the University Babes-Bolyai, Faculty of Chemistry and Chemical Engineering, Cluj-Napoca, Romania.

\section{Acknowledgments}

This work was supported by a grant of the Romanian National Authority for Scientific Research, CNDI-UEFISCDI, project number PN-II-PT-PCCA-2011-3.20219 (Contract no. 176/2012).

The authors would like to thank Professor C. Sarbu, Department of Chemistry, University Babes-Bolyai, Cluj-Napoca, for the useful suggestions in statistical data analysis throughout this study.

\section{Author details}

'Faculty of Chemistry and Chemical Engineering, Babes-Bolyai University, 11 Arany Janos, 400028, Cluj-Napoca, Romania. ${ }^{2}$ National Institute for Research and Development of Optoelectronics Bucharest, Research Institute for Analytical Instrumentation, Donath 67, 400293, Cluj-Napoca, Romania.

Received: 15 July 2013 Accepted: 8 November 2013

Published: 19 November 2013

\section{References}

\begin{abstract}
Abbreviations
CV-AFS: Cold vapor atomic fluorescence spectrometry; CV-ICP-OES: Cold vapor inductively coupled plasma optical emission spectrometry; CV-ICPMS: Cold vapor inductively coupled plasma mass spectrometry; CV- $\mu C C$ OES: Cold vapor capacitively coupled plasma microtorch optical emission spectrometry; CRM: Certified reference material; TOC: Total organic carbon.
\end{abstract}

\section{Competing interests}

The authors declare that they have no competing interests.
1. Leopold K, Foulkes M, Worsfold P: Methods for the determination and speciation of mercury in natural waters - a review. Anal Chim Acta 2010, 663:127-138.

2. Diez $\mathrm{S}$, Bayona JM: Determination of $\mathrm{Hg}$ and organomercury species following SPME: a review. Talanta 2008, 77:21-27.

3. Nam DH, Basu N: Rapid methods to detect organic mercury and total selenium in biological samples. Chem Cent J 2011, 5:3.

4. Kelly JG, Han FXX, Su Y, Xia YJ, Philips V, Shi ZQ, Monts DL, Pichardo ST, Xia K: Rapid determination of mercury in contaminated soil and plant 
samples using portable mercury direct analyzer without sample preparation, a comparative study. Water Air Soil Poll 2012, 223:2361-2371.

5. Sardans J, Montes F, Penuelas J: Electrothemal atomic absorption spectrometry to determine $\mathrm{As}, \mathrm{Cd}, \mathrm{Cr}, \mathrm{Cu}, \mathrm{Hg}$ and $\mathrm{Pb}$ in soils and sediments: a review and perspectives. Soil Sediment Contam 2011, 20:447-491.

6. Guo W, Hu SH, Wang XJ, Zhang JY, Jin LL, Zhu ZL, Zhang HF: Application of ion molecule reaction to eliminate WO interference on mercury determination in soil and sediment samples by ICP-MS. J Anal At Spectrom 2011, 26:1198-1203.

7. Araujo RGO, Vignola F, Castilho INB, Borges DLG, Welz B, Vale MGR, Smichowski P, Ferreira SLC, Becker-Ross H: Determination of mercury in airborne particulate matter collected on glass fiber filters using highresolution continuum source graphite furnace atomic absorption spectrometry and direct solid sampling. Spectrochim Acta Part B 2011, 66B:378-382.

8. Leopold K, Zierhut A, Huber J: Ultra-trace determination of mercury in river waters after online UV digestion of humic matter. Anal Bioanal Chem 2012, 403:2419-2428.

9. Jew AD, Kim CS, Rytuba JJ, Gustin MS, Brown GE Jr: New technique for quantification of elemental $\mathrm{Hg}$ in mine wastes and its implications for mercury evasion into the atmosphere. Environ Sci Technol 2011, 45:412-417.

10. Pandey SK, Kim KH, Brown RJC: Measurement techniques for mercury species in ambient air. Trends Anal Chem 2011, 30:899-917.

11. Pirrone N, Cinnirella S, Feng X, Finkelman RB, Friedli HR, Leaner J, Mason R, Mukherjee AB, Stracher GB, Streets DG, Telmer K: Global mercury emissions to the atmosphere from anthropogenic and natural sources. Atmos Chem Phys 2010, 10:5951-5964

12. U.S. EPA: Office of Air quality planning \& standards and office of research and development, EPA, mercury study: report to congress, Vol III, fate of transport of mercury in the environment, EPA-452/R-97-005. 1997. http://nepis.epa.gov/Exe/ZyPURL.cgi?Dockey=2000ElCE.txt (accessed 01.05.2013).

13. Bernaus A, Gaona X, van Ree D, Valiente M: Determination of mercury in polluted soils surrounding a chlor-alkali plant: direct speciation by X-ray absorption spectroscopy techniques and preliminary geochemical characterisation of the area. Anal Chim Acta 2006, 565:73-80.

14. Garcia-Sanchez A, Murciego A, Alvarez-Ayuso E, Santa Regina I, RodriguezGonzalez MA: Mercury in soils and plants in an abandoned cinnabar mining area (SW Spain). J Hazard Mater 2009, 168:1319-1324.

15. Malferrari D, Brigatti MF, Elmi C, Laurora A: Determination of $\mathrm{Hg}$ binding forms in contaminated soils and sediments: state of the art and a case study approaching abandoned mercury mines from Mt. Amiata (Siena, Italy). Neues Jahrbuch Fur Mineralogie-Abhandlungen 2011, 188:65-74.

16. Rodrigues S, Pereira ME, Duarte AC, Ajmone-Marsan F, Davidson CM, Grcman H, Hossack I, Hursthouse AS, Ljung K, Martini C, Otabbong E, Reinoso R, Ruiz-Cortes E, Urquhart GJ, Vrscaj B: Mercury in urban soils: a comparison of local spatial variability in six European cities. Sci Total Environ 2006, 368:926-936

17. Tack FMG, Vanhaesebroeck T, Verloo MG, Van Rompaey K, Van Ranst E: Mercury baseline levels in Flemish soils (Belgium). Environ Pollut 2005, 134:173-179.

18. Neculita CM, Zagury GJ, Deschenes L: Mercury speciation in highly contaminated soils from chlor-alkali plants using chemical extractions. J Environ Qual 2005, 34:255-262.

19. EPA 3200 method: mercury species fractionation and quantification by microwave assisted extraction, selective solvent extraction and/or solid phase extraction. U.S. environmental protection agency. http://www.epa. gov/osw/hazard/testmethods/pdfs/3200.pdf (accessed 01.05.2013).

20. Butcher DJ: Review: recent advances in optical atomic spectrometry. Appl Spectrosc Rev 2013, 48:261-328.

21. Long Z, Luo YM, Zheng CB, Deng PC, Hou XD: Recent advance of hydride generation-analytical atomic spectrometry: part I - technique development. App/ Spectrosc Rev 2012, 47:382-413.

22. Long Z, Chen C, Hou XD, Zheng CB: Recent advance of hydride generation-analytical atomic spectrometry: part II - analysis of real samples. App/ Spectrosc Rev 2012, 47:495-517.

23. Bings NH, Bogaerts A, Broekaert JAC: Atomic spectroscopy. Anal Chem 2013, 85:670-704.

24. Cerveny V, Horvath M, Broekaert JAC: Determination of mercury in water samples by electrochemical cold vapor generation coupled to microstrip microwave induced helium plasma optical emission spectrometry. Microchem J 2013, 107:10-16.

25. Jamroz P, Pohl P, Zyrnicki W: Spectroscopic evaluation of a low power atmospheric pressure mixed argon-helium microwave induced plasma combined with the chemical generation of volatile species for the optical emission spectrometric determination of arsenic, antimony and mercury. J Anal At Spectrom 2012, 27:1772-1779.

26. Frentiu T, Mihaltan Al, Darvasi E, Ponta M, Roman C, Frentiu M: A novel analytical system with a capacitively coupled plasma microtorch and a gold filament microcollector for the determination of total $\mathrm{Hg}$ in water by cold vapour atomic emission spectrometry. J Anal At Spectrom 2012, 27:1753-1760.

27. Frentiu T, Mihaltan Al, Ponta M, Darvasi E, Frentiu M, Cordos E: Mercury determination in non- and biodegradable materials by cold vapor capacitively coupled plasma microtorch atomic emission spectrometry. J Hazard Mater 2011, 193:65-69.

28. Frentiu T, Mihaltan Al, Senila M, Darvasi E, Ponta M, Frentiu M, Pintican BP: New method for mercury determination in microwave digested soil samples based on cold vapor capacitively coupled plasma microtorch optical emission spectrometry: comparison with atomic fluorescence spectrometry. Microchem J 2013, 110:545-552.

29. Schollenberger CJ: Determination of soil organic matter. Soil Sci 1945, 59:53-56.

30. Levei E, Frentiu T, Ponta M, Tanaselia C, Borodi G: Characterization and assessment of potential environmental risk of tailings stored in seven impoundments in the Aries river basin, Wester Romania. Chem Cent $J$ 2013, 7:5.

31. Abbollino O, Malandrino M, Giacomino A, Mentasi E: The role of chemometrics in single and sequential extraction assay: a review: part I. Extraction procedures, uni- and bivariate techniques and multivariate reduction techniques for pattern recognition. Anal Chim Acta 2011, 688:104-121.

32. Zhou F, Guo H, Liu Z, Jiang Y: Chemometrics data analysis of marine water quality and source identification in Southern Hong Kong. Mar Pollut Bull 2007, 54:745-756.

33. Bland JM, Altman DG: Measuring agreement in method comparison studies. Stat Methods Med Res 1999, 8:135-160.

34. Rytuba JJ: Mercury from mineral deposits and potential environmental impact. Environ Geol 2003, 43:326-338.

35. Kocman $\mathrm{D}$, Horvat $\mathrm{M}$, Kotnik J: Mercury fractionation in contaminated soils from the Idrija mercury mine region. J Environ Monitor 2004, 6:696-703.

36. Molina JA, Oyarzun R, Esbri JM, Higueras P: Mercury accumulation in soils and plants in the Almaden mining district, Spain; one of the most contaminated sites on Earth. Environ Geochem HIth 2006, 28:487-498.

37. Ministerial Order No. $756 / 1997$ Approving the regulation concerning the assessment of environmental pollution. Official Gazette 1997. Part I, no. 303bis/06.11.1997 [in Romanian].

38. Hakanson L: Ecological risk index for aquatic pollution control. A sedimentological approach. Water Res 1995, 14:975-1001.

39. Ministerial Order No. 95/2005 for the approval of waste acceptance criteria and national list of waste accepted in each landfill class. Official Gazette 2005. Part I, no. 194/08.03.2005 [in Romanian].

40. Shao D, Kang Y, Wu S, Wong MH: Effects of sulfate reducing bacteria and sulfate concentrations on mercury methylation in freshwater sediments. Sci Total Environ 2012, 424:331-336.

41. Kinniburg GG, Jackson ML: Absorption of mercury (II) by iron hydrous oxide gel. Soil Sci Soc Am J 1978, 42:45-47.

42. Geffery PG: Chemical methods of rock analysis. 2nd edition. Oxford: Pergamon; 1975

43. Renneberg AJ, Dudas MJ: Calcium hypochlorite removal of mercury and petroleum hydrocarbons from co-contaminated soils. Waste Manage Res 2002, 20:468-475.

\section{doi:10.1186/1752-153X-7-178}

Cite this article as: Frentiu et al:: Determination, speciation and distribution of mercury in soil in the surroundings of a former chloralkali plant: assessment of sequential extraction procedure and analytical technique. Chemistry Central Journal 2013 7:178. 